\title{
KAJIAN FILOSOFIS REVEALED KNOWLEDGE DI UNIVERSITAS ISLAM NEGERI SYARIF HIDAYATULLAH JAKARTA
}

\author{
Dewi Nur Syahidah \\ UIN Walisongo Semarang \\ Email: syahida_1808016023@student.walisongo.ac.id \\ Nurul Embun Isnawati \\ UIN Walisongo Semarang \\ nurul_embun_1808026026@student.walisongo.ac.id
}

Ahmad Fery Nafiul Umam

UIN Walisongo Semarang

nafiul_1808016021@student.walisongo.ac.id

\author{
Ahmad Fauzan Hidayatullah \\ UIN Walisongo Semarang \\ afhidayatullah@walisongo.ac.id
}

\begin{abstract}
Abstrak
Tujuan dari pembuatan jurnal ini adalah untuk mengetahui kajian secara filosofis mengenai revealed knowledge yang diterapkan di UIN Syarif Hidayatullah. Revealed knowledge merupakan penempatan wahyu sebagai sumber dari ilmu pengetahuan. Wahyu diberikan kepada manusia melalui perantara Nabi sebagai petunjuk bagi kehidupan manusia. Manusia memperoleh kebenaran dan pengetahuan atas dasar wahyu. Universitas Islam Negeri Syarif Hidayatullah merupakan satu dari sekian banyak universitas Islam yang ikut serta dalam menerapkan revealed knowledge. Kajian filsafat ilmu menyatakan bahwa, secara umum metode mencari pengetahuan adalah dengan melalui pendekatan rasionalisme, empirisme, dan metode keilmuan. Metode-metode yang digunakan dalam mencari pengetahuan, pada dasarnya semuanya bertujuan untuk memperoleh kepastian, Tetapi perlu disadari bahwa kebenaran yang dicapai manusia hanyalah kebenaran berdasarkan sudut pandang pendekatan yang digunakan. Ditinjau dari filosofisnya pada dasarnya universitas islam di seluruh indonesia mempunyai landasan atau misi yang sangat mulia, akan tetapi tidak semuanya berjalan dengan baik, setidaknya misi yang mulia itu akan berdampak positif pada sebagian besar mahasiswa. Metode yang digunakan dalam penyusunan jurnal ini adalah dengan deskriptif kualitatif, yaitu menelusuri jurnal-jurnal yang relevan sebagai sumber literatur kemudian digeneralisasi melalui pemikiran penulis.
\end{abstract}

Kata Kunci: Filosofis, Revealed Knowledge, UIN Syarif Hidayatullah. 


\begin{abstract}
The purpose of making this journal is to find out philosophical studies regarding revealed knowledge that is applied at UIN Syarif Hidayatullah. Revealed knowledge is the placement of revelation as a source of knowledge. Revelation was given to humans through the Prophet's intermediaries as a guide for human life. Humans acquire truth and knowledge on the basis of revelation. Syarif Hidayatullah State Islamic University is one of the many Islamic universities that has participated in applying revealed knowledge. The study of philosophy of science states that, in general the method of seeking knowledge is through an approach of rationalism, empiricism, and scientific methods. The methods used in seeking knowledge are basically all aimed at obtaining certainty, but it needs to be realized that the truth achieved by humans is only the truth based on the point of view of the approach used. Judging from the philosophy, basically Islamic universities throughout Indonesia have a very noble foundation or mission, but not everything goes well, at least this noble mission will have a positive impact on most students. The method used in the preparation of this journal is descriptive qualitative, that is, tracing the relevant journals as a source of literature and then generalizing through the author's thoughts.
\end{abstract}

Keywords: Philosophical, Revealed Knowledge, UIN Syarif Hidayatullah.

\title{
Pendahuluan
}

Dalam prespektif Islam, ilmu pengetahuan ialah hasil dari suatu upaya yang bersungguh-sungguh (ijtihad) dari ilmuwan-ilmuwan muslim atas persoalan duniawi atau ukhrawi yang bersumber pada wahyu Allah. Al-quran dan hadits adalah wahyu Allah SWT yang diberikan kepada Nabi Muhammad SAW melalui malaikat Jibril dengan cara berangsur-angsur yang digunakan sebagai petunjuk bagi umat manusia, termasuk petunjuk dalam keilmuan dan kegiatan ilmiah. Hal ini dapat dilihat dalam Surah Al-Alaq ayat 1 yang mempunyai arti sebagai berikut, "Bacalah, dengan (menyebut) nama Tuhanmu yang telah menciptakan". Berdasarkan ayat tersebut dapat diketahui bahwa Alquran sangat memperhatikan suatu ilmu (Kosim, 2008).

Revealed knowledge merupakan bentuk dari ilmu yang mendukung pemikiran luhur yaitu suatu jenis pemikiran yang tinggi martabatnya berdasarkan ketauhidan, kewahyuan, keimanan, dan ketakwaan. Dalam ajaran Islam revealed knowledge dicontohkan seperti ilmu tauhid dan ilmu ushuluddin. Manusia memiliki ilmu pengetahuan berupa ilmu ukhrawi yang mengarah kepada ilmu naqliyah atau revealed knowledge dan ilmu duniawi yang meliputi akal atau acquired knowledge agar dapat menjalankan tugasnya kepada Allah SWT sebagai seorang hamba dan khalifah sesama 
manusia (Soelaiman, 2013). Jika berbicara tentang ilmu keislaman tidak terlepas dari proses perkembangan dan penyebaran Islam kepada masyarakat. Pada empat belas abad yang lalu, Rosulullah telah gigihnya menyebarkan misi islam yang notabennya adalah wahyu kerasulannya. Selama bergulirnya waktu kurang lebih 23 tahun, beliau telah mampu mengukuhkan keberadaan Islam. Sepeninggalan beliau, kepemimpinan umat Islam dilanjutkan oleh Khulafaur Rasyidin, Bani Abbasiyyah, Bani Umayyah hingga saat ini masih berlanjut. Ilmu pengetahuan berkembang dan berakselerasi berdasarkan pedoman dan tuntunan yang diwariskan oleh umat Islam. perkembangan ilmu pengetahuan, terutama ilmu keislaman dari hari ke hari semakin tersebar dilihat dari kehidupan masyarakat yang mayoritas beragama Islam. Dilihat dari kepastian ilmu keislaman yang menunjukkan cabang-cabang ilmu yang berakar dari Al-quran. Walaupun kadang kala mengalami stagnasi pemikiran dikarenakan kelalaian dan kejumudan para ahli yang mengalami kemunduran di suatu masa. Untuk lebih lengkapnya dapat ditinjau di sub selanjutnya. (Nelvawita, 2017).

Revealed Knowledge dapat diartikan sebagai ilmu yang berasal dari wahyu. Keberadaan revealed knowledge ini dapat menjadi salah satu upaya kebangkitan dunia Islam dalam hal pengetahuan, setelah sekian lama terpuruk semenjak peristiwa westernisasi besar-besaran yang kian mengubah kiblat pengetahuan masyarakat Islam kepada dunia barat. Eksistensi perguruan tinggi Islam menjadi salah satu komponen penting dalam upaya perealisasian revealed knowledge. Sudah seharusnta perguruan tinggi Islam menjadikan kurikulum revealed knowledge sebagai misi utamanya.

Jurnal ini memaparkan bagaimana kajian filosofis mengenai revealed knowledge di UIN Syarif Hidayatullah, sebagai salah satu elemen yang ikut serta dalam upaya pemurnian terhadap kembalinya wahyu sebagai sumber utama ilmu pengetahuan. Jurnal ini menggunakan metode deskriptif kualitatif dengan menelusuri jurnal-jurnal yang relevan, kemudian digeneralisasi melalui pendapat penulis.

\section{Sejarah Revealed Knowledge}

Ibnu Khaldun mengklasifikasikan ilmu menjadi dua yaitu ilmu naqliyah dan ilmu aqliyah. Ilmu naqliyah meliputi ilmu hadits, ilmu kalam, ilmu tafsir, ilmu qira'ah, dan ilmu fiqih. Berdasarkan sumber tersebut, ilmu-ilmu agama merupakan suatu 
pengaplikasian dari revealed knowledge agar manusia dapat menyempurnakan tugasnya sebagai hamba Allah SWT (Hariyati \& Fistiyanti, 2017).

Pada masa kenabian Nabi Muhammad SAW ilmu-ilmu agama yang berkaitan dengan peradaban Islam mulai berkembang. Dalam hal ini proses dakwah nabi merupakan awal dari perkembangan ilmu agama. Sejarah peradaban Islam dibagi menjadi tiga periode yaitu (Nasution,2018):

1. Periode klasik ( kurang lebih pada tahun $650-1258 \mathrm{M}$ )

Pada periode ilmu pengetahuan berkembang dengan baik, dalam bidang agama, umum, kebudayaan, dan peradaban Islam. Di masa ini muncul ulama-ulama besar seperti Imam Malik, Imam Abu Hanifah, Imam Syafi'i dan Imam Hambal dalam bidang Ilmu Fiqih. Pada bidang Teologi menghasilkan ulama besar seperti Imam Asy'ari, Imam AlMaturidi. Wasil ibn Ata', Abu Huzail, Al-Nazzam dan Al-Zubba'i. Pada bidang ilmu tasawuf menghasilkan ulama besar seperti Zunun al-Miasri, Abu Zayid Al-Bustami dan Al-Hallaj. Dan pada bidang filsafat menghasilkan ulama besar seperti Al-Kindi, AlFarabi, Ibn Sina, dan Ibnu Miskawaih.

2. Periode pertengahan (pada abad ke-17 M)

Pada masa ini ilmu pengetahuan kurang diperhatikan, karena umat Islam sedang mengalami masa kemunduran. Hasilnya pada masa ini Baghdad jatuh di penghujung abad ke-17 M.

3. Periode modern (mulai abad ke-18 sampai sekarang)

Pada masa ini raja-raja dan para pemuka Islam mulai memikirkan kembali bagaimana cara meningkatkan mutu dan kekuatan umat Islam. Timbulah banyak pemikiran dan ide mengapa umat Islam lemah, mundur, dan bagaimana mengatasinya, serta perlu adanya pembaruan dalam Islam. Hasilnya pada masa ini umat Islam mengalami kebangkitan. Berikut merupakan beberapa masa perkembangan peradaban Islam pada periode modern :

a. Masa Khulafaur Rasyidin

Setelah Nabi Muhammad SAW wafat, peradaban Islam dilanjutkan oleh para sahabat (Abu Bakar Ash-Shidiq, Umar bin Khattab, Usman bin Affan dan Ali bin Abi 
Thalib) yang disebut masa Khulafaur Rasyidin. Namun perkembangan ilmu-ilmu agama terjadi pada masa kepemimpinan Umar bin Khattab, karena pada masa Abu Bakar AshShidiq dan Usman bin Affan lebih menekankan pada perluasan wilayah dan kodifikasi mushaf Al-quran. Sedangkan pada masa Ali bin Abi Thalib sudah muncul berbagai macam kerusuhan sehingga perkembangan ilmu agama kurang diperhatikan. terjadi penaklukan-penaklukan Islam di Persia, Syam (Syiria), Mesir, dan lain-lain. Pada periode sejarah Khulafaur rasyidin manusia betul-betul berada dalam manhaj Islam yang benar (Widodo, 2017)

Menurut Nasution (2018) pada masa kekhalifahan Umar bin Khattab terdapat ilmu-ilmu agama seperti Ilmu Qira'at, Ilmu Tafsir, Ilmu Hadist, Ilmu Nahwu dan Ilmu Fikih.

- Ilmu Qira 'at, merupakan ilmu tentang tata cara membaca Al-quran, karena pada masa itu banyak orang Islam yang belum bisa membaca Al-quran sehingga menimbulkan kekhawatiran akan terjadinya banyak kesalahan dalam membacanya. Sehingga Khalifah Umar mengutus Muadz bin jabal ke Palestina, Ibadah bin al-Shamit ke Hims, Abu Darda' ke Damaskus, ubai bin Ka'ab dan Abu Ayub tetap di Madinah.

- Ilmu Tafsir, berguna dalam memahami ayat-ayat Al-Qur'an. Beberapa sahabat telah ada yang menafsirkan Al-Qur'an, sesuai dengan yang mereka terima dari Rasulullah. Diantaranya adalah Ali bin Abi Thalib, Abdullah bin Abbas, Abdullah bin Mas'ud, dan Abdullah bin Ka'ab.

- Ilmu Hadist, pada masa khalifah umar terdapat sahabat yang diutus untuk menyebarkan hadits ke wilayah-wilayah islam, seperti Abdullah bin Mas'ud ke Kufah,Ma'qal bin Yasar ke Basrah, Ibadah bin Samid dan Abu Dardak ke Syiria. Namun pada masa ini rasulullah melarang menulis hadits karena dikhawatirkan akan bercampur dengan Al-Qur'an. Sehingga, hadis Rasul pada masa khulafa' al-Rasyidu belum dibukukan. Usaha pembukukan yaitu pada masa khalifah Umar bin Abdul al-Aziz.

- Ilmu Nahwu, ilmu tata bahasa tentang mempelajari bahasa arab. Pembina dan penyusun pertamanya adalah Ali bin Abi Thalib.

- Ilmu Fikih, berguna untuk menentukan ketetapan hukum karena semakin banyak permaslahan yang dihadapi umat Islam. Beberapa sahabat mempunyai keahlian 
dalam bidang fikih seperti Umar bin Khattab, Ali bin Abi Thalib, Zaid bin Tsabit yang tinggal di Madinah, Abdullah bin Abbas yang tinggal di Makkah, Abdullah bin Mas'ud yang tinggal di Kufah, Anas bin Malik tinggal di Basrah, Muadz bin Jabal tinggal di Syiria, dan Abdullah bin Amr bin Ash tinggal di Mesir.

b. Masa Dinasti Umayyah I (Syiria)

Dinasti Umayyah memiliki pusat pemerintahan di Syiria yang berdiri pada tahun 661-750 M. Perkembangan ilmu agama berlanjut pada masa Dinasti Umayyah antara lain Ilmu Qira 'at, Ilmu Tafsir, Ilmu Hadist, Ilmu Fiqih, Ilmu Bahasa, Ilmu Kalam, dan Ilmu Tasawuf. Pada masa ini ilmu agama berkembang secara stabil. Pada masa ini juga hadits pertama kali dibukukan pada awal abad kedua Hijriah.Ilmu kalam membahas tentang keilmuan dengan menggunakan argumen, akal atau filosofis. Muncul tokoh-tokoh pada ilmu kalam dari kelompok Mu'tazilah seperti Washil bin Atha', Abu Huzail al-Jubba'i, dan Al-Nazham. Sedangkan Hasan Basri, Abu Hasan al-Asy'ari, al-Maturidi dan Imam al-Ghazali dari kelompok Sunni.Ilmu tasawuf ialah ajaran yang menekuni ibadah dan menjauhkan diri dari kesenangan duniawi. Tokoh-tokoh yang terkenal dalam ilmu tasawuf ini adalah Hasan Basri, Rabiah al-Adawiyah, Abu Yazid al-Bustami, Al-Hallaj, Al-Mishri, Ibnu Al-Arabi, dan Jalaludin al-Rumi (Nasution, 2018).

c. Masa Dinasti Umayyah II (Spanyol)

Pusat pemerintahan terletak di Spanyol tahun 756-1492 M. Pada masa ini banyak dibangun universitas-universitas dan memiliki sekitar 75 perpustakaan pada masa khalifah Abdurrahman III. Ilmu-ilmu agama yang berkembang antara lain (Nasution, 2018):

1. Ilmu filsafat

Abu Bakar Muhammad bin al-Sayigh yang dikenal dengan Ibnu Bajjah merupakan tokoh pertama fisafat Arab-Spanyol. Kemudian penerus pemikiran filsafatnya adalah Ibn Thufail yang memiliki karya berjudul Hay ibn Yaqzhan. Tokoh yang ketiga adalah Ibn Rusyd yang merupakan pengikut Aristoteles yang terbesar di gelanggang filsafat dalam Islam. Pembahasan pada karya-karyanya selalu dibagi menjadi komentar, kritik dan pendapat.

2. Ilmu fiqih 
Dalam bidang ilmu ini, Spanyol banyak menganut Mazhab Maliki yang diperkenalkan oleh Ziyad bin Abdul al-Rahman.

d. Masa Dinasti Abbasiyah (Baghdad)

Kemenangan tentara Islam masa Al-Mahdi dan Harun Al-Rasyid atas Bizantium, memunculkan gerakan intelektual dalam sejarah Islam. Setelah tercapai kemenangan dalam peperangan, para tentara membuka jalan bagi bidang pemerintahan, keuangan, undang-undang dan ilmu pengetahuan untuk berkarya di bidangnya. Dengan demikian maka muncul penyair, filsuf, ahli sejarah, ahli ilmu hisab, tokoh agama dan pujangga yang memperkaya khazanah bahasa Arab. Disebabkan masuknya pengaruh asing, yaitu; Yunani, Suriah, India, Persia dan Yahudi. Gerakan intelektual ditandai dengan proyek penerjemahan karya-karya berbahasa Persia, Sanskerta, Suriah (aramaik) dan Yunani ke dalam bahasa Arab.

Menurut Nelvawita (2017) ilmu-ilmu agama mulai berkembang sangat pesat pada masa Dinasti Abbasiyah. Dapat dijumpai bahwa banyak ilmuwan-ilmuwan muslim yang terkemuka. Pada pemerintahan Harun al-Rasyid banyak dibangun madrasah dan perpustakaan. Adapun ulama-ulama Islam yang terkenal yaitu Imam Abu Hanifah dan Imam Malik. Ahli dalam bidang filosof antara lain al-Farabi yang mendapat julukan $\mathrm{Al}$ Muallim al-Tsani (guru kedua setelah Aristoteles), Ibnu Sina dengan karyanya al-Mantiq, al-Ghazali yang dikenal sebagai Hujjatul Islam dan lain-lain.

Ilmu pengetahuan mengalami perkembangan pesat pada Dinasti Abbasiyah (Nasution, 2018). Demikian dengan ilmu agama, hal itu dapat dilihat pada perkembangan ilmu filsafat yang melahirkan para filsuf besar. Menurut Hariyati (2017) khalifah Harun al-Rasyid dan al-Makmum mendukung perkembangan ilmu pengetahuan dan peradaban Islam dengan mensponsori penerjemahan buku-buku dan yang berisi khazanah ilmu pengetahuan dari peradaban seperti Yunani, Persia, dan India. Penerjemahan dan pengembangan ilmu dipusatkan di Baitul Hikmah.

Peradaban Islam mengalami puncak kejayaan pada masa Dinasti Abbasiyah. Perkembangan ilmu pengetahuan sangat maju, diawali dengan penerjemahan naskah asing terutama Yunani ke dalam bahasa Arab. Pendirian pusat pengembangan ilmu dan perpustakaan Bait Al-Hikmah dan terbentuk mahzab ilmu pengetahuan dan keagamaan 
sebagai buah kebebasan berpikir. Kemajuan peradaban Abbasiyah disebabkan stabilitas politik dan kemakmuran ekonomi kerajaan. Para penerjemah tidak hanya dari kalangan Islam, namun juga pemeluk Nasrani (Syiria) dan Majusi (Persia). Pada masa tersebut dikenal ahli agama antara lain Imam Syafì i yang pernah mengajar fiqh di Baqdad. Imam Abu Hanifah, Imam Malik dan Imam Syafì i menolak menjadi Qadi Dinasti Abbasiyah. Selain itu juga banyak muncul tokoh dalam bidang keilmuan masing-masing misalnya: Yahya ibn Haris, Hamzah ibn Habib, Abu Abdurrahman Al Muqri, Khalaf ibn Hisyam, Abdullah ibn Abbas, Muqatil ibn Sulaiman, Muhammad ibn Ishak, Imam Muslim, Ibnu Muqaffa dll. Adanya tokoh-tokoh intelektual menjadi bukti konkret kemajuan Islam yang identik dengan The Golden Age (Oktaviyani, 2018).

\section{Revealed Knowledge dalam Kajian Filosofis}

Kajian filsafat ilmu menyatakan bahwa umumnya cara mencari pengetahuan ialah melalui pendekatan raisonalisme, emperisme dan metode keilmuan. Keseluruhan cara atau upaya yang dipakai dalam mencari pengetahuan pada dasarnya bertujuan memperoleh kebenaran, akan tetapi perlu disadari bahwa kebenaran yang dicapai manusia hanyalah kebenaran berdasarkan sudut pandang pendekatan yang digunakan. Sementara itu, kebenaran mutlak atau yang disebut kebenaran wahyu bersumber dari Alquran dan Hadits (Baiti \& Harith, 2018).

Secara mudah filsafat ilmu itu sendiri dapat didefinisikan sebagai suatu kajian yang akan menjawab pertanyaan tentang hakikat ilmu, ditinjau dari ontologi, epistemologi, dan aksiologi. Hal ini dilakukan secara sistematis dan mendalam. Sehingga filsafat ilmu tidak berpanjang lebar menjelaskan tentang sejarah dari filsafat, teori dan konsep yang ada dalam diri filsafat, berbagai cabang filsafat, melainkan membahas substansi dari filsafat itu sendiri. Hal ini dikarenakan inti dari pembahasan yang ada tidak lain dan tidak bukan ada dalam tiga aspek pembahasan; ontologi, epistemologi, dan aksiologi yang satu dengan lainnya saling berkaitan erat, hingga kemudian melahirkan suatu disiplin ilmu baru (Tiswardini, 2019)

a. Ontologi

Adapun aspek pertama ialah ontologi, secara bahasa Yunani terdiri dari dua kata; on: being, dan logos; Logic. Jadi ontology ialah The theory of being qua being atau teori 
tentang keberadaan sebagai keberadaan. Sementara menurut istilah ontology ialah ilmu yang membahas tentang hakikat yang ada, berbentuk jasmani/konkret maupun rohani/abstrak . Hal senada juga menurut sumber lain disebutkan bahwa ontologi itu membahas apa yang ingin kita ketahui, seberapa jauh kita ingin tahu, atau dengan perkataan lain, suatu pengkajian mengenai teori tentang "ada". Ontology merupakan pembahasan dalam rangka untuk mencari atau mendapatkan hakekat sesuatu. Sering orang mempertanyakan kembali 'sesuatu' apa ? atau 'sesuatu' yang manakah ? yaitu sesuatu apa saja, baik berbentuk benda materi atau non-materi atau sering disebut dengan istilah abstrak. Hingga kemudian kita mendapatkan 'hakekat' dari sesuatu tersebut, seperti yang dahulu pernah dilakukan oleh filosof Yunani bernama Thales. Thales berkesimpulan setelah melewati perenungan tentang air, ia mengatakan bahwa air itu adalah substansi terdalam atau asal dari segala sesuatu, karena dengan air itulah kehidupan bisa berjalan dan kehidupan itu bisa berkembang. Tanpa suatu kajian ontologi tentang suatu hal, mustahil adanya suatu pembahasan yang mendalam dan melebar karena secara akar pembahasan belum terungkap. Namun sebaliknya jika suatu kajian telah dikaji secara ontologis maka serta merta akan mengungkap berbagai hal yang berkaitan dengan kajian tersebut, sehingga akan muncul berbagai macam hal yang ada hubungannya dengan akar kajian yang sedang dibahas. (Tiswardini, 2019).

\section{b. Epistimologi}

Epistemologi adalah cara mendapatkan pengetahuan yang benar, karena epistemologi itu adalah teori pengetahuan, tidak lain dan tidak bukan merupakan kelanjutan yang tak terpisahkan dari ontologi seperti yang telah dijelaskan di atas. Tanpa pemahaman yang utuh tentang ontologi dari 'suatu hakekat', mustahil kita akan dapat memahami dan menjawab dari pertanyaan "apa" yang sedang kita cari jawabannya. Hal senada juga dengan aspek epistemologi atau teori pengetahuan dari sesuatu, yang berurusan dengan hakikat dan lingkup pengetahuan, pengandaian-pengandaian, dasardasar, dan pertanggungjawaban tentang pengetahuan yang dimilikinya. Proses pencarian epistemology atau teori suatu pengetahuan yang sedang kita amati dan kita cari, biasanya didasarkan atas pertimbangan sikap skeptis, karena dengan sikap ragu itulah orang mencari tahu tentang berbagai hal yang melingkupinya. Maka dari sinilah kemudian lahir berbagai pengetahuan baru yang tergali tentang sesuatu tersebut (Tiswardini, 2019) 
Pembahasan mengenai sarana, sumber dan metode ilmu pengetahuan dalam Filsafat Ilmu disebut dengan epistemologi yang di dalamnya membicarakan tentang definisi ilmu pengetahuan dan cara memperolehnya. Dalam epistemologi Islam, sumber ilmu pengetahuan berasal dari fisik dan non-fisik. Dengan ini telah jelas bahwa sumber pengetahuan dalam Islam yaitu alam fisik yang dapat diindra dan alam metafisik yang tidak dapat diindra, misalnya Tuhan, malaikat, alam kubur dan alam akhirat. Dalam epistemologi Islam, ilmu pengetahuan dapat dicapai dengan tiga elemen yaitu indra, akal dan hati (Kosim, 2008). Epistemologi memiliki dasar yang cukup kuat. Selama inu, telah ada pandangan dan keyakinan bahwa Islam mengarahkan supaya pengembangan ilmu pengetahuan dilakukan secara utuh yakni bersumber pada ayat-ayat qauliyah (Al-quran dan Hadits) dan ayat-ayat kauniyah (hasil observasi, eksperimen dan penalaran logis) (Hariyati \& Fistiyanti, 2017).

\section{c. Aksiologi}

Secara bahasa aksiologi berasal dari perkataan Axios (bahasa Yunani) yang berarti nilai, dan kata Logos yang berarti; teori, jadi aksiologi mengandung pengertian ; teori tentang nilai. Sementara secara umum aksiologi dapat diartikan sebagai teori nilai yang berkaitan dengan kegunaan dari pengetahuan yang diperoleh Dari berbagai capaian manusia yang telah didapat dari ilmu pengetahuan dan teknologi, telah banyak memberikan daya manfaat dan daya guna bagi kehidupan manusia selama ini. Namun demikian selama temuan yang dihasilkan oleh ilmu pengetahuan dan teknologi itu memberikan bermanfaat dan berguna tidaklah masalah, tetapi pertanyaan selanjutnya adalah jika temuan teknologi itu berbentuk senjata dan sejenisnya. secara aksiologi atau teori nilai yang berkaitan dengan kegunaan dari suatu pengetahuan yang didapat oleh manusia, dengan sendirinya dapat dikategorikan akan memberi manfaat dan berguna ataukah sebaliknya. Maka dalam perkembangan berikutnya kajian filsafat yang membahasa tentang aksiologi ini melahirkan dua cabang filsafat yang kelak akan menjadi salah satu cabang induk suatu pengetahuan; etika dan estetika. Karena bagaimanapun juga manusia tidak hanya dituntut untuk bertindak dan berperilaku saja, tetapi nilai perilakunya seorang manusia itu memiliki nilai daya guna atau sebaliknya merugikan orang lain. Kemudian dikembangkan kajian ini menjadi kajian etika dan estetika dalam ilmu pengetahuan manusia hingga kini (Tiswardini, 2019) 
Agar dapat menghasilkan sumber daya manusia yang seimbang dari prespektif Islam, harus diterapkan suatu konsep terpadu yakni jenis pendidikan dan pelatihan yang membimbing dan melatih pikiran, tubuh serta jiwa berdasarkan pada nilai-nilai keislaman dan wahyu-wahyu seperti Al-Qur'an dan Hadits (Sunnah). Pendidikan Islam Terpadu menekankan pada kesatuan pengetahuan, bukan hanya instalasi atau imitasi dari pengetahuan seseorang melalui praktik pembelajaran konvensional. Adapun konsep dari pendidikan holistik yang mencakup aspek integrasi pendidikan antara lain Tuhan, alam semesta, pengetahuan, nilai-nilai, keterampilan dan keberadaan manusia serta keterkaitannya (Hasmori, Yunos, Hamzah, \& Aripin, 2015).

\section{Revealed Knowledge di Universitas Islam Negeri Syarif Hidayatullah Jakarta}

IAIN Syarif Hidayatullah Jakarta sebagai salah satu IAIN tertua di Indonesia yang bertempat di Jakarta, menempati posisi yang unik dan strategis. Ia tidak hanya menjadi "Jendela Islam di Indonesia", tetapi juga sebaga simbol bagi kemajuan pembangunan nasional, khususnya di bidang pembangunan sosial-keagamaan. Sebagai upaya untuk mengintegrasikan ilmu umum dan ilmu agama, lembaga ini mulai mengembangkan diri dengan konsep IAIN dengan mandat yang lebih luas (IAIN with Wider Mandate) menuju terbentuknya Universitas Islam Negeri Syarif Hidayatullah Jakarta. Universitas Islam Negeri (UIN) Syarif Hidayatullah. Penamaan Syarif Hidayatullah diambil dari nama asli tokoh besar Islam, Sunan Gunung Jati. Universitas ini bukan sekadar menjadi institusi pembelajaran ataupun riset yang menciptakan lulusan berkualias. UIN Syarif Hidayatullah Jakarta juga menjadi institusi yang turut menyumbangkan programprogram peningkatan kesejahteraan sosial demi masyarakat luas. (https://campus.quipper.com/directory/universitas-islam-negeri-syarif-hidayatullahjakarta).

Sejak 2007 UIN Syarif Hidayatullah menetapkan motto "Knowledge, Piety, Integrity". Motto ini pertama kali disampaikan Rektor UIN Syarif Hidayatullah Jakarta, Prof. Dr. Komaruddin Hidayat, dalam pidato Wisuda Sarjana ke-67 tahun akademik 2006-2007. Knowledge mengandung arti bahwa UIN Syarif Hidayatullah memiliki komitmen menciptakan sumber daya insani yang cerdas, kreatif, dan inovatif. UIN Syarif Hidayatullah Jakarta berkeinginan memainkan peranan optimal dalam kegiatan learning, discoveries, and engagement hasil-hasil riset kepada masyarakat. Komitmen tersebut 
merupakan bentuk tanggung jawab UIN Syarif Hidayatullah Jakarta dalam membangun sumber insani bangsa yang mayoritas adalah Muslim. UIN Syarif Hidayatullah Jakarta ingin menjadi sumber perumusan nilai keislaman yang sejalan dengan kemodernan dan keindonesiaan. Oleh karena itu, UIN Syarif Hidayatullah Jakarta menawarkan studi-studi keislaman, studi-studi sosial, politik, ekonomi, sains dan teknologi modern dalam perspektif integrasi ilmu. Piety mangandung pengertian bahwa UIN Syarif Hidayatullah Jakarta memiliki komitmen mengembangkan inner quality dalam bentuk kesalehan di kalangan sivitas akademika. Kesalehan yang bersifat individual (yang tercermin dalam terma habl min Allah) dan kesalehan sosial (yang tercermin dalam terma habl min al-nas) merupakan basis bagi sivitas akademika UIN Syarif Hidayatullah Jakarta dalam membangun relasi sosial yang lebih luas. Integrity mengandung pengertian bahwa sivitas akademika UIN Syarif Hidayatullah Jakarta merupakan pribadi yang menjadikan nilainilai etis sebagai basis dalam pengambilan keputusan dan perilaku sehari-hari. Integrity juga mengandung pengertian bahwa sivitas akademika UIN Syarif Hidayatullah Jakarta memiliki kepercayaan diri sekaligus menghargai kelompok-kelompok lain. Dalam moto "Knowledge, Piety, Integrity" terkandung sebuah spirit untuk mewujudkan kampus madani, sebuah kampus yang berkeadaban, dan menghasilan alumni yang memiliki kedalaman dan keluasaan ilmu, ketulusan hati, dan kepribadian kukuh (https://id.wikipedia.org/wiki/Universitas_Islam_Negeri_Syarif_Hidayatullah_Jakarta)

UIN Syarif Hidayatullah Jakarta memiliki Fakultas Ushuluddin yang sangat tekenal sejak era 1980-an, dikenal sebagai fakultas yang 'sangar' dalam pemikiran filsafatnya. Karena telah dikursus Filsafat barat dan Islam Kontemporer yang cukup kental. Pada Fakultas Ushuluddin memiliki jurusan antara lain Studi Agama-Agama, Akidah Filsafat, dan Tafsir Hadist. Secara umum, sejak tahun 1960-an menguatnya paham dan praktik keislaman masyarakat Indonesia yang sangat tradisional dan juga berpengaruh pada keislaman dimana-mana, termasuk kajian ushuluddin di UIN Syarif Hidayatullah (dulunya IAIN) (Bahri, 2018). Dengan demikian implementasi revealed knowlwdge telah dipraktikkan pada perguruan tinggi di Indonesia sejak dulu.

Menurut kajian filosofis, ada 3 aspek penting yang perlu disoroti yaitu ontologi, epistimologi dan aksiologi. Dalam mengkaji Revealed Knowledge di UIN Syarif Hidayatullah perlu diperlukan 3 aspek tersebut. 


\section{a. Ontologi}

Ontologi merupakan ilmu yang membahas mengenai hakikat yang ada berdasarkan logika yang ada. Di UIN Syarif Hidayatullah khususnya pada Fakultas Ushuludin, terdapat 8 program studi, diantaranya : Studi Agama-Agama, Aqidah dan Filsafat Islam, Ilmu Al-quran dan Tafsir, Ilmu Hadits, Ilmu Tasawuf, Magister Studi Agama-Agama, Magister Aqidah dan Filsafat Islam, dan Magister Ilmu Al-quran dan Tafsir.

Kajian PA atau dikenal dengan studi agama-agama terdiri atas tiga hal pokok, yaitu akidah atau pemikiran keagamaan dalam agama-agama, ritual dalam agama-agama, dan aspek persekutuan, Sejak berdiri hingga saat ini area pokok keilmuan SAA adalah pertama materi tentang agama-agama dunia dan kepercayaan yang masih hidup (living religions and beliefs) seperti Hinduisme, Buddhisme, Yudaisme, agama-agama lokal, agama-agama minor, aliran kepercayaan dan lain-lainSalah satu buku babon studi PA adalah karya klasik Joachim Wach, The Comparative Study of Religions (1958). Buku ini masih dipakai oleh program studi PA hingga kini. Dalam buku itu, Wach menjelaskan bahwa ekspresi (ungkapan) pengalaman keagamaan mengambil tiga bentuk utama, yaitu dalam pemikiran, perbuatan, dan persekutuan (fellowship). perkumpulan atau organisasi, atau aspek sosial. Jika yang pertama memakai pendekatan yang normatif semisal fenomenologis, maka yang ketiga adalah wilayah ilmu-ilmu sosial. Aspek yang kedua, yaitu ritual bisa dengan pendekatan normatif bisa juga dengan pendekatan ilmu-ilmu sosial tergantung pada fokus kajiannya. Karena itu Wach sendiri menegaskan bahwa ungkapan dalam bentuk persekutuan bukan suatu tambahan dari dua yang lain, yaitu pemikiran dan perbuatan. Tiga aspek itu sama-sama penting (Bahri, 2018)

Pada Aqidah dan Filsafat Islam Secara spesifik wilayah kajian AFI adalah Ilmu Kalam, Filsafat Islam dan Tasawuf. Tiga kajian ini sangat khas Ushuluddin dan paling distingtif, dalam arti ilmu Syariah, Tarbiyah, Dakwah dan Adab tidak akan mengkaji tiga bidang di atas secara mendalam. Secara umum, Kalam, Filsafat Islam dan Tasawuf diurai secara lebih luas dalam subjek-subjek yang variatif. Dalam ilmu Kalam misalnya, terdapat subjek Perbandingan Aliran Kalam, Kalam Kontemporer dan Studi Naskah Ilmu Kalam. Kajian Kalam ini kemudian diperkaya oleh subjek Pemikiran Modern Dalam Islam dan Pemikiran Modern Islam di Indonesia. Dalam bidang Filsafat Islam terdapat 
subjek-subjek seperti Filsafat Islam Klasik, Filsafat Islam Pasca Ibn Rusyd, Tema-Tema Filsafat Islam dan Studi Naskah Filsafat Islam. Dalam bidang Tasawuf terdapat subjeksubjek seperti Tasawuf Klasik, Tasawuf Pasca Ibn Rusyd, Tasawuf Nusantara dan Studi Naskah Tasawuf (Bahri, 2018)

Jurusan Tafsir-Hadis (TH) dibuka di Fakultas Ushuluddin pada tahun ajaran 1989/1990 sebagai ganti dari Jurusan Dakwah yang kemudian berdiri sendiri menjadi Fakultas Dakwah. Sejak berdiri, Jurusan TH memang concern hendak mencetak ulamaulama yang ahli dalam bidang studi al-Quran, ilmu tafsir, dan ilmu hadis. Secara spesifik wilayah kajian IAT dan IH adalah ilmu-ilmu al-Quran, tafsir dan hadis. Karena itu, subjek-subjek keilmuan tradisional seperti Ulumul Quran, Ulumul Hadis, I'jaz al-Quran, Qawaid Tafsir, Takhrij Hadis, Ilmu Matan Hadis, dan Ilmu Rijal al-Hadis masih menjadi bagian yang tak terpisahkan dari keilmuan Tafsir-Hadis. Area program studi ini kemudian diperdalam oleh subjek-subjek yang lain seperti Tafsir Aqidah, Hadis Aqidah, Tafsir Ahkam, Hadis Ibadah dan Ahkam, Metode Istinbath Hukum dalam al-Quran dan Hadis, Studi Naskah Tafsir dan Hadis, dan Tafsir Ijtima'i. Dalam konteks pengembangan kajian Tafsir dan Hadis subjek-subjek kontemporer telah masuk pula dalam area keilmuan IAT seperti Metode Penelitian Tafsir Hadis, Pendekatan Modern Kajian al-Quran, Kajian Barat Terhadap al-Quran, Literatur Tafsir Indonesia, dan Hermeneutik dan Semiotik. Semua subjek-subjek di atas telah menunjukkan dengan jelas area keilmuan kajian IAT yang tidak akan masuk dalam keilmuan rumpun lain. Seperti halnya dalam SAA dan AFI, termasuk dalam wilayah IAT dan IH adalah living Quran, living Tafsir dan living hadis seperti kajian mengenai bagaimana ulama dan sarjana di Indonesia, Asia, Timur Tengah dan tempat-tempat lain memahami al-Quran, tafsir dan hadis (Bahri, 2018)

b. Epistimologi

Epistemologi adalah cara mendapatkan pengetahuan yang benar, karena epistemologi itu adalah teori pengetahuan, tidak lain dan tidak bukan merupakan kelanjutan yang tidak terpisahkan. Sumber pokok ilmu pengetahuan yang ada di UIN Syarif Hidayatullah beberapa diantaranya adalah Al-quran dan Hadits. Sebagai universitas yang menerapkan revealed knowledge, Al-quran dan hadits adalah dua sumber paling pokok dalam proses belajar mengajar. 
Al-Qur'an secara ilmu kebahasaan berakar dari kata qaraa yaqrau quranan yang berarti “bacaan atau yang dibaca". Secara general Al-Qur'an didefenisikan sebagai sebuah kitab yang berisi himpunan kalam Allah, suatu mukjizat yang diturunkan kepada Nabi Muhammad SAW melalui perantara malaikat Jibril, ditulis dalam mushaf yang kemurniannya senantiasa terpelihara, dan membacanya merupakan amal ibadah. AlQur'an juga merupakan pedoman hidup bagi manusia di dunia dan akhirat. Al-Qur'an memberikan dalil yang berisi khikmah dan kekuasaan-Nya bahwa Allah Maha Bijaksana dalam menciptakannya. Segala sesuatu yang diciptakan oleh allah tidak akan sia-sia, bahkan semua itu menjadi bukti dan bukti tanda-tanda kebesaran Allah SWT, bahwa Allah ada dan Allah yang maha menciptakan atas segala sesuatu yang ada di dalam alam semesta ini. Jika kita menelaah ayat-ayat di dalam Al-Qur'an maka Bukti-bukti ciptaan dan hikmah-Nya jelas nyata. Ia adalah buku induk ilmu pengetahuan, di mana tidak ada satu perkara apapun yang terlewatkan, semuanya telah terkafer di dalamnya yang mengatur berbagai asfek kehidupan manusia, baik yang berhubungan dengan Allah (Hablum minallah); sesama manusia (Hablum minannas); alam, lingkungan, ilmu akidah, ilmu sosial, ilmu alam, ilmu emperis, ilmu agama, umum dan sebgaianya.(Q.S. Al-an'am: 38). Lebih lanjut Achmad Baiquni mengatakan, "sebenarnya segala ilmu yang diperlukan manusia itu tersedia di dalam Al-Qur'an" (Iryani, 2017).

Umat Islam telah mengakui bahwa hadits Nabi SAW itu dipakai sebagai pedoman hidup yang utama setelah al-Qur'an. Ajaran-ajaran Islam yang tidak ditegaskan ketentuan hukumnya, tidak dirinci menurut petunjuk dalil yang masih utuh, tidak diterangkan cara pengamalannya dan atau tidak dikhususkan menurut petunjuk ayat yang masih mutlak dalam al-Qur'an, maka hendaknya dicarikan penyelesaiannya dalam hadits. Dalam kaitan ini, hadits berfungsi sebagai petunjuk dan isyarat bagi alQur'an yang bersifat global, sebagai pengecuali terhadap isyarat al-Qur'an yang bersifat umum, sebagai pembatas terhadap ayat al-Qur'an yang bersifat mutlak, juga sebagai pemberi informasi terhadap suatu kasus yang tidak dijumpai dalam al-Qur'an. Dengan demikian, maka pemahaman al-Qur'an dan juga pemahaman ajaran Islam yang seutuhnya tidak dapat dilakukan tanpa mengikutsertakan hadits Nabi SAW. Hadits merupakan sesuatu yang sangat penting untuk dipelajari dan diteliti kebenarannya karena hadits adalah sumber kedua yang berfungsi sebagai bayan yaitu menjelaskan ayat-ayat al-Qur'an yang masih global sebagaimana pendapat Imam Malik yang dikutip oleh Rohmansyah bahwa hadits 
mempunyai empat fungsi utama yang menghubungkan dengan al-Qur'an, yaitu berfungsi sebagai bayan al-taqrir18 yang menetapkan dan mengokohkan hukum-hukum alQur'an, bayan al-taudhih yang menjelaskan dan menerangkan maksud-maksud dari ayat alQur'an, bayan al tafshil yang menjelaskan ayat-ayat yang masih mujmal dan bayan al basthi (tabsith dan takwil) yakni memanjangkan keterangan yang masih ringkas dalam al-Qur'an (Khotimah, 2018)

\section{c. Aksiologi}

Secara aksiologi atau teori nilai yang berkaitan dengan kegunaan dari suatu pengetahuan yang didapat oleh manusia, dengan sendirinya dapat dikategorikan akan memberi manfaat dan berguna ataukah sebaliknya. Bagi seorang muslim kegunaan studi agama-agama banyak manfaat yang diperoleh diantaranya : Mempelajari agamaagama selain islam akan memberikan pengetahuan dan pemahaman yang lebih komprehensif tentang proses evolusionistik Wahyu Tuhan kepada manusia dan hubungan antara Islamdengan agama-agama sebelumnya. Islam sebagai sebuah peradaban yang pernah berdiri memimpin peradaban lainnya selama berabad-abad tentu bukan soal remeh temeh, terutama yang sering dinilai dari kacamata sosial dan historis. Nilai sebuah peradaban adalah berdasarkan struktur pemikiran dan ideologinya yang kemudian mewarnai berbagai prestasinya baik secara kultural dan saintifik. Dari sini sudah barang tentu sejauh mana berbagai pencapaian oleh peradaban Islam itu dihasilkan merupakan manifestasi dari canggihnya tradisi pemikiran mereka. Mempelajari filsafat secara Islam adalah sebagai counter atas berbagai kontestasi para orientalis dalam bidang ini. Karena tidak jarang mereka berbuat tidak adil, manipulatif dan bias dalam kesarjanaannya, entah itu mereduksi fakta, mendistorsi sejarah atau menutupinya. Seringkali Islam hanya dianggap peniru, penjiplak dan pengepul warisan-warisan dari tradisi lain, bagi mereka Islam tidak mempunyai tradisi rasional

\section{Penutup}

Revealed knowlwdge merupakan suatu bentuk wahyu yang datang dari Allah swt. yang disampaikan kepada nabi Muhammad saw. berupa dalil naqli atau yang dihimpun menjadi kitab suci Al-Qur'an. Didalam Al-Qur'an terdapat ilmu-ilmu yang berupa naqliyah yang dipelajari sebagai ilmu-ilmu agama. Ilmu agama meliputi Ilmu Qira'at, Ilmu Tasawuf, Ilmu Tafsir, Ilmu Fiqih dan lain-lain. Dalam perkembangannya ilmu-ilmu 
agama mengalami banyak kemajuan. Namun ada kalanya ilmu agama juga mengalami kemunduran, hal itu disebabkan oleh faktor politik ataupun pemerintahannya. Pada masa tertentu umat islam mengalami kerusuhan yang mengakibatkan ilmu kurang mendapat perhatian, baik ilmu agama maupun ilmu pengetahuan.secara umum metode-metode dalam kajian filsafat adalah dengan melalui pendekatan rasionalisme, empirisme, dan metode keilmuan. Dalam Universitas Islam Negeri Syarif Hidayatullah jaakrta mempunyai pemikiran filsafat yang sangat terkenal karena pada era 1980-an Sudah dikursus filsafat barat dan kontemporer.

\section{DAFTAR PUSTAKA}

Bahri, M. Z. (2018). Ilmu-Ilmu Ushuluddin Uin Syarif Hidayatullah Jakarta Menatap Masa Depan: Sebuah Pemetaan Keilmuan.

Baiti, R., \& Harith, M. (2018). Esensi Wahyu Dan Ilmu Pengetahuan. Wardah, 18(2), 163. Https://Doi.Org/10.19109/Wardah.V18i2.1776

Hariyati, M., \& Fistiyanti, I. (2017). Sejarah Klasifikasi Ilmu-Ilmu Keislaman Dan Perkembangannya Dalam Ilmu Perpustakaan. Pustakaloka, 9(1), 147-164.

Hasmori, A. A., Yunos, J. M., Hamzah, R., \& Aripin, M. A. (2015). Revealed Knowledge Integration In National Dual Training System (Ndts): Philosophy, Issues, And Challenges. Procedia - Social And Behavioral Sciences, 204(November 2014), 191-197. Https://Doi.Org/10.1016/J.Sbspro.2015.08.135

Iryani, E. (2017). Al- Qur'an Dan Ilmu Pengetahuan. Jurnal Ilmiah, 17(3), 66-83.

Khotimah, I. H. (2018). Studi Hadits : Polemik Hadits Sebagai Sumber Ajaran Islam. Jurnal Hikmah, 4(8), 1-17.

Kosim, M. (2008). Ilmu Pengetahuan Dalam Islam (Perspektif Filosofis-Historis). Jurnal Tadris, 3(2), 121-140. Retrieved From Http://Tadris.Stainpamekasan.Ac.Id/Index.Php/Jtd/Article/Download/55/110

Nelvawita. (2017). Akselerasi Perkembangan Ilmu Keislaman (Suatu Analisis Filosofis). Potensia: Jurnal Kependidikan Islam, 3(2), 242-255.

Oktaviyani, V. E. (2018). Ilmu Pengetahuan Dan Teknologi Dinasti Abbasiyah Periode Pertama. Juspi: Jurnal Sejarah Peradaban Islam, 2(2), 183-193.

Soelaiman, D. A. (2013). Filsafat Ilmu Pendidikan Untuk Indonesia. Pencerahan, 7(2), 80-89. Https://Doi.Org/10.13170/Jp.7.2.2036 
Tiswardini, D. (2019). Tiga Aspek Utama Dalam Kajian Filsafat Ilmu; Ontologi, Epistemologi, Dan Aksiologi. Seminar Nasional Bahasa Dan Sastra Indonesia Sasindo Unpam 2019, 1(2), 141-146.

Widodo. (2017). Objek Kajian Dan Urgensi Mempelajari Sejarah Dan Peradaban Islam. Jurnal Ilmiah Pedagogy, 8(1), 1-5.

https://id.wikipedia.org/wiki/universitas_islam_negeri_syarif_hidayatullah_jakarta diakses pada 7 Agustus 2020

https://campus.quipper.com/directory/universitas-islam-negeri-syarif-hidayatullahjakarta diakses pada 7 Agustus 2020 